\title{
Drinking Water Source Protection in the Tampa Bay Region: A Guide for Homeowners ${ }^{1}$
}

Amy L. Shober ${ }^{2}$

\section{Introduction and Purpose}

Do you ever wonder about the source and quality of the water that comes into your home via the public water supply? We often take for granted that water will flow whenever we turn on the tap, and that it will be cleanand safe to drink. Most of us don't think about where the water comes from, let alone the effort required to deliver clean water. The purpose of this publication is to familiarize homeowners in the Tampa Bay region with the local sources of drinking water, potential pollution sources, and actions that can protect the quality of the local drinking water supply.

\section{Sources of Drinking Water in the Tampa Bay Region}

Drinking water in the Tampa Bay region comes from a vast below-ground aquifer system (ground water), as well as from surface water supplies such as lakes, reservoirs, and streams. By 2012,

approximately $50 \%$ of the region's drinking water will come from ground water supplies and 50\% from surface water (e.g. Hillsborough River, Alafia River and Tampa Bypass Canal).

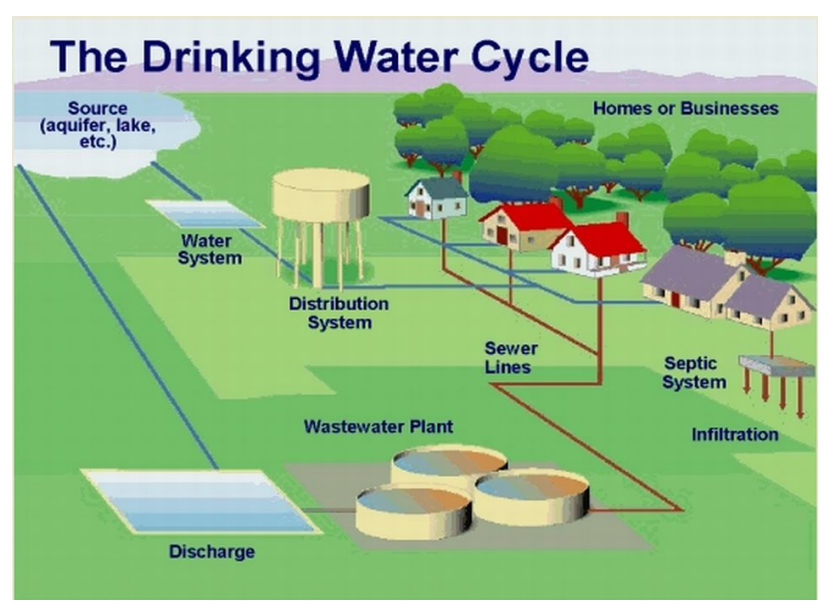

Figure 1. Example of a public water supply system.

Most homeowners in the Tampa Bay region obtain their drinking water from the public supply. Figure 1 shows an example of a public water system. In the Tampa Bay region, Tampa Bay Water is the wholesale water supplier to Hillsborough, Pasco and Pinellas counties and the cities of Tampa, St. Petersburg, and New Port Richey. Tampa Bay Water delivers approximately 182 million gallons of drinking water from 13 regional well fields, the Hillsborough River, the Alafia River, the Tampa Bypass Canal and the Tampa Bay Desalinization

1. This document is SL280, one of a series of the Soil and Water Science Department, Florida Cooperative Extension Service, Institute of Food and Agricultural Sciences, University of Florida. Original publication date February 2009. Visit the EDIS Web Site at http://edis.ifas.ufl.edu.

2. Amy L. Shober, assistant professor, Department of Soil and Water Science, Center for Landscape Conservation and Ecology, Gulf Coast Resarch and Education Center--Balm FL; Florida Cooperative Extension Service, Institute of Food and Agricultural Sciences, University of Florida, Gainesville, FL 32611.

The Institute of Food and Agricultural Sciences (IFAS) is an Equal Opportunity Institution authorized to provide research, educational information and other services only to individuals and institutions that function with non-discrimination with respect to race, creed, color, religion, age, disability, sex, sexual orientation, marital status, national origin, political opinions or affiliations. U.S. Department of Agriculture, Cooperative Extension Service, University of Florida, IFAS, Florida A. \& M. University Cooperative Extension Program, and Boards of County Commissioners Cooperating. Millie Ferrer, Interim Dean 
Plant. This water is delivered to the member governments through more than 200 miles of pipeline in the region. More information about the current supplies of water can be found at the Tampa Bay Water's Web site (http://www.tampabaywater.org/index.aspx).

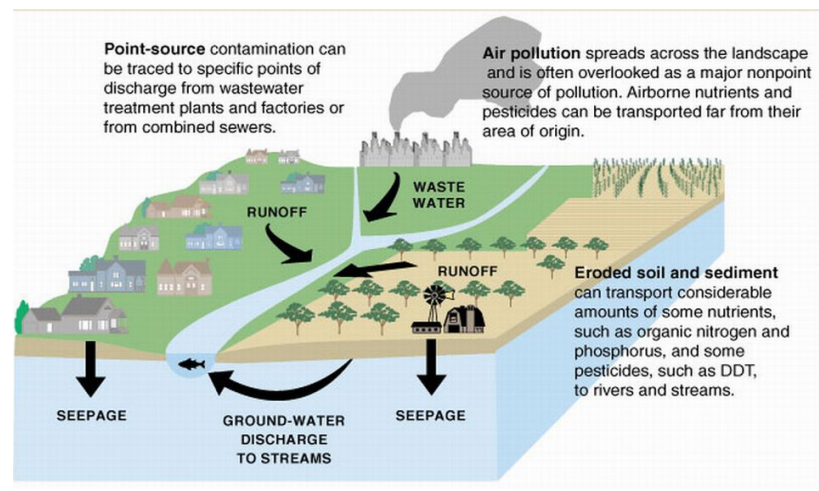

Figure 2. Potential sources of drinking water contamination.

\section{Potential Sources of Drinking Water Contamination}

In the Tampa Bay region, regional water supply sources were once located in relatively remote locations. However, population growth and land development in the region have situated these drinking water sources in close proximity to developed urban and suburban areas. As a result, the risk for contamination of drinking water sources is increasing. Potential drinking water pollutants originate from point sources, such as wastewater treatment plants and industrial outflows, and non-point sources, such as runoff or leachate (water that moves through the soil to the groundwater) from urban, suburban, industrial and agricultural areas (Figure 2). Some of the potential contaminants of drinking water supplies include:

Microorganisms: Most microscopic organisms are not harmful, but some, such as E. coli (a bacteria) and Cryptosporidium (a protozoan) can make you sick if found in drinking water. The most common sources of microorganism contaminants in drinking water come from human and animal wastes. Animal sources of microorganisms can be natural wildlife or animal agriculture, while human sources can come from malfunctioning septic systems.
Radioactive elements: Some contaminants, such as radon gas, can emit radioactivity. Radon is a naturally occurring gas that can be dissolved in water. The source of radon in drinking water is the breakdown of rocks that contain the gas.

Inorganic contaminants: Examples of inorganic contaminants include lead, arsenic, nitrate and phosphate. Lead can come from degraded water pipes, while nitrate and phosphate may come from the use of fertilizers or animal wastes left on the soil in agricultural and urban areas. Regional mining operations may also be a source of phosphates.

Organic contaminants: Organic chemicals can originate from chemical spills or leaking storage tanks. For example, gasoline or oil may be spilled on the ground or leak from underground storage tanks. Pesticides that are used in agricultural and urban areas can also be a source of organic contaminants.

Pharmaceuticals and personal care products: Medications that are flushed down the drain and/or excreted from human bodies may find their way into the drinking water supply, as can products like anti-microbial soaps, sunscreens, and cosmetics.

\section{Government Actions to Protect Drinking Water}

In Florida, the Department of Environmental Protection (DEP) is responsible for regulating public water systems, which are defined as any facility that provides drinking water to at least 25 people or 15 connections, at least 60 days per year. The FL Department of Environmental Protection requires that levels of potential contaminants in water delivered through the public supply do not exceed levels set by the U.S. Environmental Protection Agency. This is done to ensure that the water delivered through the public supply is clean and safe. Each year, Tampa Bay Water performs thousands of water tests to ensure the quality of the water delivered through their system. (Tampa Bay water provides an annual water quality report online at http://www.tampabaywater.org/watersupply/ waterquality.aspx.)

In addition to efforts by the FL Department of Environmental Protection, there are many local 
government efforts to ensure the safety and reliability of the regions drinking water. For example, county and city governments in the region have passed land development ordinances, acquired sensitive lands near drinking water sources, and reviewed and modified proposals for land development to ensure that wellheads and surface water sources are protected from pollution.

\section{Activities that Help to Protect Drinking Water}

There are some simple things that you can do to help protect the local sources of drinking water in your area. Do your part by:

1. Using best management practices when fertilizing landscapes to avoid nutrient pollution.

2. Limiting pesticide applications.

3. Purchasing and using environmentally friendly household chemicals.

4. Using all medications and personal care products instead of washing them down the drain.

5. Disposing of household chemicals (e.g., paint, motor oil, gasoline, cleaning products, etc.) at designated facilities.

6. Maintaining septic systems by having regular inspections and tank pumping.

7. Having unused wells closed by a professional.

8. Joining a community environmental group to help spread the word!

\section{Summary}

Protection of drinking water sources is important to ensure that the citizens of the Tampa Bay Region continue to receive safe, clean and reliable drinking water. It is important that citizens also do their part to limit pollution and wasteful use of the water supply. Simple things like proper use and disposal of fertilizers and household chemicals can go a long way to help keep our drinking water clean.

\section{References}

USEPA. 2002. Consider the source: A pocket guide to protecting your drinking water. United States Environmental Protection Agency, Washington, D.C. Available at http://www.epa.gov/safewater/sourcewater/pubs/ guide_swppocket_2002.pdf. Verified January 19, 2009.

USEPA. 2004. Drinking water contaminants. United States Environmental Protection Agency, Washington, D.C. Available at http://permanent.access.gpo.gov/lps21800/ www.epa.gov/safewater/hfacts.html. Verified January 19, 2009.

USEPA. 2008. Disinfection Byproducts: A Reference Resource. United States Environmental Protection Agency, Washington, D.C. Available at http://www.epa.gov/enviro/html/icr/ gloss_dbp.html\#dbp. Verified January 19, 2009. 